\title{
Corporate Social Responsibility and Managerial Bonus Systems
}

\author{
Luciano Fanti $^{1}$ • Domenico Buccella ${ }^{2}$
}

Received: 12 September 2017 / Accepted: 29 March 2018 / Published online: 17 April 2018

(C) The Author(s) 2018

\begin{abstract}
This paper analyses the effects of managerial delegation on the equilibrium outcomes in a duopoly market in which firms adopt corporate social responsibility (CSR) behaviours (approximately measured, as usual, by their sensitivity to consumer surplus). In particular, the endogenous choice between the most common manager's bonus schemes-i.e. sales delegation (D), "relative profits" (RP) and "pure CSR objective function" (PCSR) - is investigated making use of a standard game-theoretic approach. It is shown that the sub-game perfect Nash equilibrium is given by the common choice of the RP scheme, whereas the CSR firm's objective function would be highest (lowest) under the PCSR (D) choice. Therefore, the well-known prisoner's dilemma nature of the managerial delegation game holds also when firms adopt CSR behaviours. Overall, these findings shed new light on the issue of the managerial delegation in the recently increasing cases of socially concerned firms.
\end{abstract}

Keywords CSR · Managerial delegation · Duopoly

JEL Classification $\mathrm{L} 13 \cdot \mathrm{L} 21 \cdot \mathrm{M} 14$

Electronic supplementary material The online version of this article (https://doi.org/10.1007/s40797018-0074-6) contains supplementary material, which is available to authorized users.

Domenico Buccella

buccella@kozminski.edu.pl

Luciano Fanti

lfanti@ec.unipi.it

1 Department of Economics and Management, University of Pisa, Via Cosimo Ridolfi, 10, 56124 Pisa, PI, Italy

2 Department of Economics, Kozminski University, ul. Jagiellońska 57/59, 03-301 Warsaw, Poland 


\section{Introduction}

The separation between ownership and control as well as managers' behaviours departing from the pure profit maximization are long lasting stylised facts, especially in large companies (e.g. Berle and Means 1932). As known, the managerial economics and agency theory have first attempted to explain the reasons of the observed separation between ownership and control (e.g. Baumol 1958; Holmström 1982). However, in the second half of the 1980s, Vickers (1985), Fershtman and Judd (1987) and Sklivas (1987) (VFJS for short) have shown, by resorting to a modern game-theoretic approach, that the rationale for the separation between ownership and control might be essentially based on strategic reasons: hiring managers instructed to behave more aggressively in the market, forcing rivals to reduce output, raises market share and profits. Furthermore, while the original VFJS's approach deals with a managerial contract based on a combination of profits and sales or revenues (D), another incentive scheme that accounts for the relative performance of firms (RP) has been considered, motivated by empirical research outcomes (Gibbons and Murphy 1990; ${ }^{1}$ Salas Fumás 1992; Miller and Pazgal 2002). ${ }^{2}$ However, the rather paradoxical result of both types of managerial contract is that, although it is always convenient for an owner to conduct managers towards non-profit-maximising behaviours, if also owners in rival firms hire managers to delegate output decisions, the final results are such that, at equilibrium, firms end up in a prisoner's dilemma with relatively lower profits.

However, both approaches (D and RP) traditionally analyse profit-seeking firms, while in recent years the number of firms adopting corporate social responsibility (CSR) behaviours is rapidly increasing, and the debate on firms' social responsibility has also more and more frequently involved the academic literature (e.g. Baron 2001, 2009; Baron and Diermeier 2007; Jensen 2001; Goering 2007, 2008; Lambertini and Tampieri 2010; Benabou and Tirole 2010; Besley and Ghatak 2010).

Indeed, according to KPMG, CSR behaviours are undoubtedly a mainstream business practice across the world: $73 \%$ of 4500 companies surveyed in 45 countries in 2015 have reported the completion of CSR activities, with an increase of $2 \%$ points since 2013 and $9 \%$ points since 2011 . Notably, in 2015, 92\% among the world's largest 250 companies, in which ownership and control are clearly separated, records CRS activities (KPMG 2011, 2013, 2015). The Reputation Institute (2016) CSR survey confirms that the world's top ten companies with the best CSR reputations are worldwide, widely known, large managerial companies; in fact, the first ten places in the global ranking are as follows: (1) Rolex; (2) The Walt Disney Company; (3) Google; (4) BMW; (5) Daimler; (6) Lego; (7) Microsoft; (8) Canon; (9) Sony; (10) Apple.

\footnotetext{
1 A reason for the gaining popularity of the "relative profits" scheme is provided by Gibbons and Murphy (1990) who, as noted by Jansen et al. (2009, p. 142) “build on Holmstrom's (1982) agency argument to develop an economic theory of managerial relative performance evaluation, arguing that, in so doing, the measurement (and compensation) of managerial performance in an industry can be partially isolated from industry shocks".

2 For a recent re-examination of the properties of these types of managerial contracts see Fanti et al. (2017).
} 
Therefore, it is natural to ask if the established results of the managerial literature also hold true under the modern CSR behaviour by competing firms. This paper attempt to carry out this task.

The preceding literature studying the issue of managerial delegation with firms of CSR-type is rather scant. Exceptions are, to the best of our knowledge, four recent articles: Goering (2007), Kopel and Brand (2012), Manasakis et al. (2014) and Fanti and Buccella (2017). However, those papers model CSR following completely different approaches. Indeed, the first two and the latter papers belong to the branch of the literature on CSR which measures the firm's social interests through the consideration of the consumer surplus in the firm's objective function (while the consumers' demand is not affected by the firms' social engagement) to be maximised in the competition on product market, which leads by itself to an increased quantity and reduced profits. On the contrary, the third paper belongs to the branch which assumes that the firm's social concerns are well-valued by consumers which increase their demand ${ }^{3}$ : this approach leads not only to a larger quantity by itself, but also to higher prices and, ultimately (provided that costs to produce CSR-type goods are not prohibitively high) higher profits. The current paper belongs to the former above-mentioned branch, motivated by the fact that, in the words of Kopel $(2015,560)$ "consumers (beside shareholders) emerge as the most important stakeholder group when it comes to having an impact on a firm's approach to sustainability." Therefore, for the sake of comparison with the present paper, we briefly review only the three above-mentioned papers which share with the present one the representation of the social concern of the firm through an objective which is a combination of profits and consumer surplus.

Goering (2007) examines a mixed duopoly in which a private non-profit firm (that is, a firm with CSR features) competes with a private profit-maximising, and only the non-profit firm's stakeholders may hire their managers (while the other firm is assumed to be without managers). Kopel and Brand (2012) amend Goering's model showing that if one firm is of CSR-type and the other firm is of profit-seeking type, then at the sub-game Nash equilibrium (SPNE) both firms choose to delegate; thus, the exogenous Goering's assumption that only the firm of CSR-type hires managers is not robust. In particular, Kopel and Brand (2012) study the endogenous determination of the choice whether to hire managers in an exogenously assumed mixed duopoly.

Fanti and Buccella (2017) assume as exogenously given the presence of sales delegation in both duopolistic firms and, differently from the other papers above mentioned, develop a game for determining whether both firms, only one firm or neither firms choose CSR rules at equilibrium. They show that at the SPNE both firms' owners follow CSR rules, so attributing a sound game-theoretic fundament to this seemingly unprofitable behaviour. Moreover, rather counter-intuitively, they show that, at the equilibrium, an increase in the firms' "social concern" may actually decrease consumer surplus and increase firms' profitability. The latter finding leads the authors to conclude that "owners can find beneficial to delegate to managers engaged in CSR activities to improve the firms' profitability."

\footnotetext{
3 In particular, Manasakis et al. (2014) assume that socially responsible attributes attached to products are considered as credence goods by consumers which form expectations about their existence and level.
} 
Those contributions, however, do not consider the full spectrum of common manager's bonus schemes that, in the standard profit-seeking firms context, are denoted as "sales delegation" (D), "relative profits" (RP) and "pure profits" (PM). However, when firms are of CSR-type, the component common to all these schemes is no longer the pure profit but the objective function of the "socially concerned" firm, that is, the pure profit plus a share of the consumer's welfare. For the sake of simplicity we keep the same notation with regard to the first two bonus schemes, while we denote the third one-which is based on only the CSR objective function-as "pure CSR" (PCSR). Moreover, neither they study the endogenous choice whether to hire managers in a duopoly in which both firms are of CSR-type, nor they compare their findings with those of the standard managerial delegation literature. ${ }^{4}$

The aim of this paper is to extend the managerial delegation literature with firms of CSR-type, by investigating whether and how the firms' CSR behaviours affect the established results of such a literature, taking into account different managerial contracts schemes. We find that the SPNE is given by the common choice of the RP scheme, whereas the CSR firm's objective function would be highest under the P choice (and lowest under the D choice). Therefore, the well-known prisoner's dilemma nature of the managerial delegation game also holds when firms adopt CSR behaviours.

We contribute to the managerial delegation literature in three essential ways. First, we consider firms of CSR-type. Second, we explicitly explore models in which firms may differ in terms of their managerial remuneration policies. Third, we focus on an expanded analysis of three different managerial remuneration policies.

The paper proceeds as follows. Section 2 introduces the model. Section 3 develops the model under common managers' contracts, while Sect. 4 studies the cases of types of managers' contract different between the two firms. Section 5, exploiting the models in Sects. 3 and 4, develops the game in which owners can freely choose in a simultaneous and independent way their managerial bonus system, by looking at the emergence of Nash equilibria in pure strategies and discusses the main results with their implications. Section 6 outlines the conclusions.

\section{The Model}

We assume the following standard linear inverse market demand

$$
p=a-q_{i}-q_{j}
$$

where $p$ denotes price and $q_{i}$ and $q_{j}$ are the firms' output levels for $i, j=1,2$ and $i \neq j$. For tractability, the two firms are assumed to have zero production costs. Therefore, profits are given by

\footnotetext{
4 Under the standard firms' profit-seeking context, the strategic consequences of the use of this set of three different managerial bonus systems have been studied by Jansen et al. (2009, 2012) and Manasakis et al. (2011), showing that if owners can freely choose between these three remuneration systems for maximising their profits the "relative profits" scheme RP turns out to be the strictly dominant one.
} 


$$
\pi_{i}=\left(a-q_{i}-q_{j}\right) q_{i}
$$

Following the recent established literature (e.g. Goering 2007, 2008; Lambertini and Tampieri 2010, 2011), we assume in our model that all the social concerns can be interpreted as part of consumer surplus, and thus the feature of a CSR firm is to be sensitive to it. Therefore, we suppose that the firm, in its objective, wishes to maximise profits plus the consumer surplus that accrues to its stakeholders. ${ }^{5}$ Hence, we define the inclusion of a fraction of the market consumer surplus $k$ as the firm's "social concern" or care for consumer outcomes in the market. As a consequence, the CSR firm's objective function may be specified as a simple parameterised combination of profits and consumer surplus. Although we consider symmetric firms (having identical marginal costs), nothing prevents that their' social concern' may be different because the two firms have different owners or different boards with likely different sensitivity. Therefore, the factor $k$ could be in principle different across firms. However, following a vast literature (e.g. Lambertini and Tampieri 2010, 2012, 2015; Kopel and Brand 2012; Lambertini et al. 2016; Fanti and Buccella 2016; Planer-Friedrich and Sahm 2017), we assume that the value of $k$ is common for all the firm which operate within the industry. Thus the CSR objective function $(W)$ is:

$$
W_{i}=\pi_{i}+k C S=\left(a-q_{i}-q_{j}\right) q_{i}+k \frac{\left(q_{i}+q_{j}\right)^{2}}{2},
$$

where $k \in[0,1]$ denotes the weight that CSR firm assigns to consumer surplus. Goering $(2007,2008)$ attributes this objective function also to the non-profit organizations (NPO) which compete in commercial markets, such as sectors like University bookstores (Schiff and Weisbrod 1991), water utility, rail track maintenance company, private air-traffic control organization (Bennett et al. 2003) and even in the high-tech markets (Benz 2005). Thus, commercial NPOs selling their output and services, which provide them revenues, may be considered in the same manner as CSR firms.

From an operative point of view, the timing of the game is as follows. At stage 1 , each firm decides the weight $b$ of the managerial contract. At stage 2, managers compete in quantities. The equilibrium concept considered is the subgame perfect equilibrium by backward induction.

\section{Managerial Firms}

\section{1 "Pure CSR Objective Function" Maximising Firms}

In this case both firms hire managers by using a "pure CSR objective function" bonus scheme. ${ }^{6}$ At stage 2, the analysis is carried out as usual through the maximisation of

\footnotetext{
5 Note that this objective function is coherent with the following two interpretations: (1) the owners have "social preferences", and (2) a firm is governed by a board composed by profit-oriented owners and stakeholders interested to consumer's welfare. In the remainder of the paper these two interpretations are perfectly interchangeable.

${ }^{6}$ According to a different interpretation, firms do not hire managers and are managed by CSR-oriented owners.
} 
(3) with respect to the quantity and solving the system of the two reaction functions. Thus, one gets the equilibrium output in the case of PCSR scheme

$$
q^{P C S R}=\frac{a}{3-2 k}
$$

Substituting (4) in the profit equation, we obtain profits, consumer surplus and social welfare, respectively

$$
\begin{aligned}
\pi^{P C S R} & =\frac{a^{2}(1-2 k)}{(3-2 k)^{2}}, \\
C S^{P C S R} & =2\left(\frac{a}{3-2 k}\right)^{2}, \\
S W^{P C S R} & =\frac{4 a^{2}(1-k)}{(3-2 k)^{2}} .
\end{aligned}
$$

Note that the satisfaction of the non-negativity constraints on profits ultimately requires that $k \leq 0.50$ (that is, the firm's interest for the consumer's welfare has not to be excessively high). This constraint is assumed to hold throughout the paper.

Now, we assume that both firms hire a manager, delegate to her/him the output decision and each manager receives a fixed salary plus a bonus element, which is no longer based on only the CSR objective function but is related to a weighted combination between firms' objective function and a measure of (absolute or relative) performance, which may be given either by sales (i.e. sales delegation, D) or by the profit differential between firms (i.e. relative performance evaluation, RP). These two bonus schemes are the most used in the managerial delegation literature. Early empirical studies - followed by many others-showing that CEO compensations are based either on both profits and sales or on relative performance evaluation are Jensen and Murphy (1990) and Gibbons and Murphy (1990), respectively.

Moreover, we also follow the standard assumption in managerial delegation theory that the fixed component (salary) of the manager pay is chosen by the firm's owner such that the manager exactly gets his/her opportunity cost, which is normalized to zero. More specifically, we strictly follow the established literature in the formulation of the managerial bonus schemes (e.g. Vickers 1985; Fershtman and Judd 1987; Jansen et al. 2007, 2009; Fanti and Meccheri 2013; Meccheri and Fanti 2014).

\subsection{Managerial Firms with Sales Delegation (D)}

In this case, each manager receives a fixed salary plus a bonus element, which is related to a weighted combination between firms' objective and sales, according to the following:

$$
u_{i}=W_{i}+b_{i} q_{i},
$$


where the owner $i$ chooses the weight $b_{i}$ to maximize its own objective function and can be either positive or negative according to the fact that the owner provides incentives or disincentives to the manager's choice of output (sales).

Given the CSR firm's objective function (3), $u_{i}$ (which drives the manager $i$ 's utility) can be rewritten as:

$$
u_{i}^{D}=\left(a-q_{i}-q_{j}\right) q_{i}+k \frac{\left(q_{i}+q_{j}\right)^{2}}{2}+b_{i} q_{i}
$$

hence, the equilibrium of the second stage of the game (the market game) must satisfy:

$$
\frac{\partial u_{i}^{D}}{\partial q_{i}}=0,
$$

for $i, j=1,2$ and $i \neq j$. From (10), we obtain the reaction functions

$$
q_{i}\left(q_{j}, b_{i}\right)=\frac{a+b_{i}-q_{j}(1-k)}{2-k} .
$$

After the usual calculations, one gets the equilibrium output and profits as a function of the weights on quantities of the manager's bonus scheme:

$$
\begin{gathered}
q_{i}\left(b_{j}, b_{i}\right)=\frac{a+b_{i}(2-k)-b_{j}(1-k)}{3-2 k}, \\
\pi_{i}\left(b_{j}, b_{i}\right)=\frac{\left[a+b_{i}(2-k)-b_{j}(1-k)\right]\left[a(1-2 k)-b_{i}-b_{j}\right]}{(3-2 k)^{2}} .
\end{gathered}
$$

After inserting (12) and (13) in (3), firm $i$ maximises its CSR-objective function with respect to $b_{i}$ and then solving the system of the reaction functions in the bonuses space, one gets the following (symmetric) equilibrium value for $b$ (where the upper script $D$ refers to the "sales delegation" case):

$$
b_{j}=b_{i}=b^{D}=\frac{a\left(1+2 k^{2}-3 k\right)}{5-4 k} .
$$

Substituting backwards the equilibrium weight on quantities, one gets the sub-game perfect equilibrium of output, profit, consumer surplus and social welfare, respectively, ${ }^{7}$ in the delegation case:

\footnotetext{
7 The equilibrium value of the CSR-objective function, $\mathrm{W}^{\mathrm{D}}$, is reported, for economy of space in Table 1.
} 


$$
\begin{gathered}
q_{i}^{D}=\frac{a(2-k)}{5-4 k}, \\
\pi_{i}^{D}=\frac{a^{2}(2-k)(1-2 k)}{(5-4 k)^{2}}, \\
C S_{i}^{D}=2\left(\frac{a(2-k)}{5-4 k}\right)^{2}, \\
S W^{D}=\frac{6 a^{2}(1-k)(2-k)}{(5-4 k)^{2}} .
\end{gathered}
$$

Lemma 1 Profits are non-negative if and only if $k \leq 0.50$. This implies that the weight on quantities in the bonus scheme is positive, in line with the standard managerial delegation literature [as easily shown by simply inspecting (14)].

\subsection{Managerial Firms with Relative Performance (RP) Evaluation}

Under relative profit delegation, instead, a manager $i$ receives a bonus that is proportional to:

$$
u_{i}^{R P}=W_{i}+b_{i}\left(\pi_{i}-\pi_{j}\right)
$$

where $b_{i}$ can be either positive or negative, so that similar considerations as for $b_{i}^{D}$ apply: when $b_{i}>0$, the firm becomes more aggressive, putting more weight on profit differences; conversely, when $b_{i}<0$, the firm becomes more "cooperative".

Hence, the equilibrium of the second stage of the game (the market game) must satisfy:

$$
\frac{\partial u_{i}^{R P}}{\partial q_{i}}=0
$$

for $i, j=1,2$ and $i \neq j$. From (20), we obtain the reaction functions

$$
q_{i}\left(q_{j}, b_{i}\right)=\frac{a\left(1+b_{i}\right)-q_{j}(1-k)}{2 b_{i}+2-k} .
$$

After the usual calculations, one gets the equilibrium output and profits as a function of the weights on quantities of the manager's bonus scheme:

$$
\begin{gathered}
q_{i}\left(b_{j}, b_{i}\right)=\frac{a\left[b_{j}\left(1+k+2 b_{i}\right)+1+b_{i}(2-k)\right]}{\left[2 b_{j}\left(2-k+2 b_{i}\right)-2 k+3+2 b_{i}(2-k)\right]} \\
\pi_{i}\left(b_{j}, b_{i}\right)=\frac{a^{2}\left(1+b_{i}+b_{j}\right)(1-2 k)\left[1+b_{i}(2-k)+b_{j}\left(1+k+2 b_{i}\right)\right]}{\left[2 b_{j}\left(2-k+2 b_{i}\right)-2 k+3+2 b_{i}(2-k)\right]^{2}} .
\end{gathered}
$$

Maximising the CSR-objective function (3) with respect to $b_{i}$ and then solving the system of the reaction functions in bonuses space, by imposing the equality of 
the bonuses, ${ }^{8}$ one gets the following (symmetric) equilibrium value for $b$ (where the subscript $R P$ refers to the "Relative Performance" bonus case):

$$
b_{i}=b_{j}=b^{R P}=\frac{\sqrt{9-8 k}+2 k-3}{2 k} .
$$

An analytical inspection of Eq. (24) leads to the following Lemma.

Lemma 2 The higher the CSR parameter is, the lower the manager's incentive for the relative profits is. This means that "socially interested" firms tend to reward their managers for the relative performance less than those which are only "profit-seeking".

Substituting backwards the equilibrium weight on quantities, one gets the sub-game perfect equilibrium of output, profit, consumer surplus and social welfare, respectively, ${ }^{9}$ under this delegation case:

$$
\begin{gathered}
q^{R P}=\frac{2 a k}{(2 k-1) \sqrt{9-8 k}-2 k+3}, \\
\pi^{R P}=\frac{2 a^{2} k(2 k-1)[\sqrt{9-8 k}-3]}{((2 k-1) \sqrt{9-8 k}-2 k+3)^{2}}, \\
S W^{R P}=\frac{4 a^{2} k(2 k-1)(\sqrt{9-8 k}-4 k+3)}{3(\sqrt{9-8 k}-2 k+3)^{2}} .
\end{gathered}
$$

\subsection{Comparison of Outcomes Under the Three Alternative Bonus Schemes}

Now we compare the-exogenously given-equilibrium outcomes obtained above under alternative bonus schemes for managers. The comparison between the equilibrium outcomes under "sales delegation", "relative profits" evaluation and "pure CSR objective function" evaluation leads to the following Result:

Result 1 When firms are of CSR-type, the rankings, under alternative bonus schemes, with respect to profits, consumer surplus and social welfare are the following: $\pi^{P C S R}>\pi^{R P}>\pi^{D} ; C S^{D}>C S^{R P}>C S^{P C S R} ; \mathrm{SW}^{D}>S W^{R P}>S W^{P C S R} .{ }^{10}$

\footnotetext{
8 Strictly following the literature (e.g. Miller and Pazgal 2002; Jansen et al. 2009), we concentrate on the symmetric equilibrium $\left(b_{i}=b_{j}=b\right)$ of the first-stage game, finding that there is a unique positive equilibrium (note that other two equilibria implying implausibly high negative of $b$-i.e. implausible extreme cooperative behaviours - have been discarded).

9 The equilibrium value of the CSR-objective function, $\mathrm{W}^{\mathrm{RP}}$, is reported, for economy of space in Table 1. 10 Note that the literature on managerial delegation with only profit-seeking firms (that is in the absence of CSR behaviours) has established the same rankings (e.g. Jansen et al. 2009; Meccheri and Fanti 2014). Therefore, the introduction of firms' CSR behaviours does not modify the relative rankings of the three alternative bonus schemes.
} 
Proof By means of a simple comparison of the equilibrium results obtained above [see (5-7), (16-18) and (26-28)]. The details of such comparisons are standard and omitted here for economy of space and, as usual, available on request.

\section{The Managerial Delegation Game Analysis}

Now, in order to be able to find the endogenously emerging managerial bonus scheme-under CSR objectives by firms-when the latter may simultaneously and independently design their managers' contracts, we must also consider all the managerial delegation games in which firms use bonus schemes different between them (i.e. mixed behaviours).

\subsection{The Model with Mixed Behaviours (D/PCSR)}

In this section we assume that firm 1 hires a manager with a sales delegation contract $\left(b_{1} \neq 0\right)$ and firm 2 with a "pure CSR objective function" bonus scheme $\left(b_{2}=0\right)$.

Then, at the market stage, firm 1 maximises (9) with respect to $q_{1}$, and firm 2 maximises (3) with respect to $q_{2}$. Solving the system of the reaction functions of manager of firm 1 and owner of firm 2 we obtain

$$
\begin{aligned}
& q_{1}\left(b_{1}\right)=\frac{a+b_{1}(2-k)}{3-2 k}, \\
& q_{2}\left(b_{1}\right)=\frac{a-b_{1}(1-k)}{3-2 k} .
\end{aligned}
$$

As expected, an increase in $b_{1}$ increases the quantity produced where the manager is delegated and reduces the quantity produced by the rival.

Since $b_{2}=0$, in the first stage only firm 1 maximises (3), after substitution of (29) and (30), with respect to $b_{1}$. Therefore,

$$
\frac{\partial W_{1}}{\partial b_{1}}=0 \Leftrightarrow b_{1}=\frac{a(1-k)(1-2 k)}{4-3 k} .
$$

Then, the (asymmetric) equilibrium values of the bonus of player 1 (D) and player 2 (PCSR) are

$$
b_{1}^{D / P C S R}=\frac{a(1-k)(1-2 k)}{4-3 k}, \quad b_{2}^{D / P C S R}=0 .
$$


Also in this asymmetric case, we have that $b_{1}^{D / P C S R}>0$. Given Eq. (32), equilibrium values of quantity and profits of sales delegated firm 1 and firm 2 are given by ${ }^{11}$

$$
\begin{gathered}
q_{1}^{D / P C S R}=\frac{a\left(2+k^{2}-2 k\right)}{4-3 k}, \quad q_{2}^{D / P C S R}=\frac{\left(1+k-k^{2}\right)}{2(2-k)}, \\
\pi_{1}^{D / P C S R}=\frac{a^{2} k(1-2 k)\left(2+k^{2}-2 k\right)}{(4-3 k)^{2}}, \quad \pi_{2}^{D / P C S R}=\frac{a^{2} k(1-2 k)\left(1-k^{2}+k\right)}{(4-3 k)^{2}} .
\end{gathered}
$$

\subsection{The Model with Mixed Behaviours (RP/PCSR)}

In this section we assume that firm 1 hires a manager with a "relative profits" bonus scheme $\left(b_{1} \neq 0\right)$ and firm 2 with a "pure CSR objective function" bonus scheme $\left(b_{2}=0\right)$. Then, at the market stage, firm 1 maximises (19) with respect to $q_{1}$, and firm 2 maximises (3) with respect to $q_{2}$. Solving the system of the reaction functions of manager of firm 1 and owner of firm 2 we obtain

$$
\begin{aligned}
& q_{1}\left(b_{1}\right)=\frac{a\left[1+(2-k) b_{1}\right]}{3-2 k+2 b_{1}(2-k)}, \\
& q_{2}\left(b_{1}\right)=\frac{a\left[1+(1+k) b_{1}\right]}{3-2 k+2 b_{1}(2-k)} .
\end{aligned}
$$

As expected, an increase in $b_{1}$ increases the quantity produced where the manager is delegated and reduces the quantity produced by the rival.

Since $b_{2}=0$, in the first stage only firm 1 maximises (3), after substitution of (35) and (36), with respect to $b_{1}$. Therefore,

$$
\frac{\partial W_{1}}{\partial b_{1}}=0 \Leftrightarrow b_{1}=\frac{1-k}{k},
$$

Then, the (asymmetric) equilibrium values of the bonus of player 1 (RP) and player 2 (PCSR) are

$$
b_{1}^{R P / P C S R}=\frac{1-k}{k}, \quad b_{2}^{R P / P C S R}=0 .
$$

\footnotetext{
$\overline{11}$ The equilibrium values of the CSR-objective functions, $\mathrm{W}_{1}^{D / P C S R}$ and $\mathrm{W}_{2}^{D / P C S R}$, are reported, for economy of space, in Table 1.
} 
Also in this asymmetric case, we have that $b_{1}^{R P / P C S R}>0$ and $b_{1}^{R P / P C S R}$ is a decreasing function of $k$. Given Eq. (38), equilibrium values of profits of managerial firm 1 and firm 2 are given by ${ }^{12}$

$$
\pi_{1}^{R P / P C S R}=\frac{a^{2}(1-2 k)\left(2+k^{2}-2 k\right)}{(4-3 k)^{2}}, \quad \pi_{2}^{R P / P C S R}=\frac{a^{2}(1-2 k)\left(1-k^{2}+k\right)}{(4-3 k)^{2}} .
$$

\subsection{The Model with Mixed Behaviours (D/RP)}

In this section we assume that firm 1 (resp. firm 2) hires a manager with a sales delegation contract (resp. a relative profits contract).

Then, at the market stage, firm 1 maximises (19) with respect to $q_{1}$, and firm 2 maximises (3) with respect to $q_{2}$. Solving the system of the reaction functions of manager of firm 1 and manager of firm 2, we obtain

$$
\begin{gathered}
q_{1}\left(b_{1}, b_{2}\right)=\frac{a\left(b_{2} k+1\right)+b_{1}\left(b_{2} k+2-k\right)}{b_{2}+3-2 k}, \\
q_{2}\left(b_{1}, b_{2}\right)=\frac{a\left(b_{2}(1-k)+1\right)-b_{1}\left(1-b_{2}\right)(1-k)}{b_{2}+3-2 k} .
\end{gathered}
$$

As expected, an increase in $b_{1}$ increases the quantity produced by the firm 1 where the manager is incentivized for "sales" and reduces the quantity produced by the rival firm, where the manager is compensated for the "relative" profits.

In the first stage firm 1 (resp. 2) maximises (3), after substitution of (40) and (41), with respect to $b_{1}$ (resp. $b_{2}$ ).

Then, after usual calculations, the (asymmetric) equilibrium values of the bonus of player 1 (D) and player 2 (RP) are, respectively

$$
b_{1}^{D / R P}=\frac{\left.a(2 k-1)\left[3 H k-2 k^{2}-4 H-k+4\right)\right]}{4(6-5 k)(1-k)}, \quad b_{2}^{D / R P}=\frac{H-1}{2 k},
$$

where $H=\sqrt{1+4\left(k-k^{2}\right)}$. Also in this asymmetric case, we have that $b_{1}^{D / R P}>0$ and $b_{2}^{D / R P}>0$. Given Eq. (42), equilibrium values of profits of managerial firm 1 and firm 2 are given by ${ }^{13}$

\footnotetext{
12 The equilibrium values of the CSR-objective functions, $\mathrm{W}_{1}^{R P / P C S R}$ and $\mathrm{W}_{2}^{R P / P C S R}$, are reported for economy of space in Table 1.

13 The equilibrium values of the CSR-objective functions, $\mathrm{W}_{1}^{D / R P}$ and $\mathrm{W}_{2}^{D / R P}$, are reported for economy of space in Table 1.
} 


$$
\begin{aligned}
& \pi_{1}^{D / R P}=\frac{a^{2}(2 k-1)\left(H k+6 k^{2}-2 H-9 k+2\right) k\left(4 H k^{2}+4 k^{3}-11 H-10 k^{2}+8 H+3 k+4\right)}{(5 k-6)^{2}\left(H+6 k-1-4 k^{2}\right)^{2}}, \\
& \pi_{1}^{D / R P}=\frac{a^{2}(2 k-1)\left(H k+6 k^{2}-2 H-9 k+2\right) k\left(4 H k^{2}+4 k^{3}-11 H-10 k^{2}+8 H+3 k+4\right)}{(5 k-6)^{2}\left(H+6 k-1-4 k^{2}\right)^{2}} .
\end{aligned}
$$

\section{Endogenous Managerial Contractual Design}

In this section, we consider the situation in which firms can freely choose their managerial bonus system, based on either (1) only pure CSR objective function (PCSR), or (2) profits plus sales (D), (3) "relative profits" (RP). This means to add an extra stage to the previous two-stage game, namely a stage 0 , in which we allow each firm to choose between the three bonus schemes (separately analysed in Sects. 3 and 4). In other words, the timing is that, at stage 0 , each firm decides the type of bonus scheme, at stage 1 , managerial firms decide the weight $b$ of the last two types of managerial contract, and at stage 2 they compete in quantities. Although "Result 1" would suggest that it is beneficial at equilibrium for the CSR firm to hire a manager using a "pure CSR objective function" contract, a correct game-theoretic approach to the choice of delegating or not may reveal an equilibrium different from that suggested by a comparison of exogenously given equilibrium situations.

Armed with the equilibrium outcomes of all the managerial delegation games presented in Sects. 3 and 4, we build the following Table 1 in which the three strategic contractual options together with their corresponding values of the CSR objective function are presented.

Applying the standard methods to find the SPNEs, we show that a unique SPNE of this three-stage game does exist.

Given $G=\sqrt{4 k+1-4 k^{2}}$ and $H=\sqrt{9-8 k}$, we have the following matrix of the pay-offs of the three stage game (i.e. the equilibrium values of the objective function, $W$ ) under different organizational structures. To find the solutions of the game in terms of SPNE, we have to analyse the behaviour (i.e. sign) of the following nine objective differential:

$$
\begin{aligned}
\Delta_{1} & =W_{1}^{R P / P C S R}-W_{1}^{P C S R / P C S R}>0 ; \quad \Delta_{2}=W_{1}^{D / P C S R}-W_{1}^{P C S R / P C S R}>0 ; \\
\Delta_{3} & =W_{1}^{R P / P C S R}-W_{1}^{D / P C S R}=0 ; \quad \Delta_{4}=W_{2}^{D / R P}-W_{2}^{D / D}>0 ; \\
\Delta_{5} & =W_{2}^{D / R P}-W_{2}^{D / P C S R}>0 ; \quad \Delta_{6}=W_{1}^{P C S R / D}-W_{1}^{D / D}<0 ; \\
\Delta_{7} & =W_{1}^{D / R P}-W_{1}^{R P / R P}<0 ; \quad \Delta_{8}=W_{1}^{D / R P}-W_{1}^{R P / P C S R}>0 ; \\
\Delta_{9} & =W_{2}^{R P / P C S R}-W_{2}^{R P / R P}<0
\end{aligned} .
$$

Result 2 The unique SPNE of the managerial delegation game with three different bonus schemes is RP/RP. 


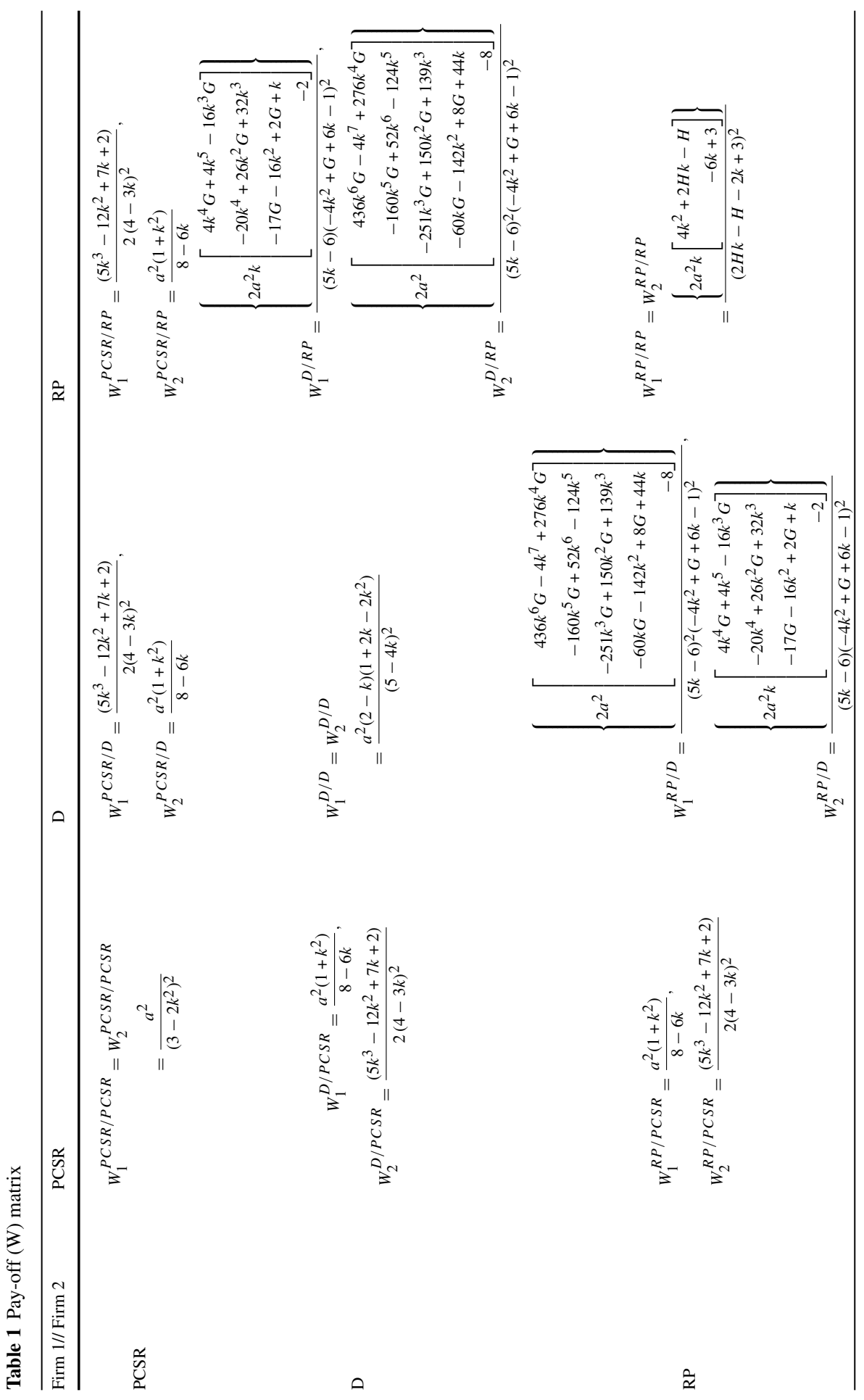


Proof It straightforwardly follows from the analysis of the signs of the involved nine objective differential as reported above.

In other words, the main conclusions is that, if firms aiming at maximising a CSR objective function can freely choose between these three remuneration schemes, the relative profits scheme RP turns out to be the strictly dominant one.

As noted by Jansen et al. (2009) (in the absence of CSR behaviour by firms) the fact that a managerial bonus based on "relative profits" turns out to be the more profitable one "confirms, in the delegation context, Holmstrom's (1982) finding that a team (here, the owner-manager team) can maximize their joint achievement by using relative performance incentives" (p. 147).

Moreover, we note that, also in the case of CSR-type firms, the well-established paradox for the case of standard profit-seeking firms that, if firms decide to remunerate managers with a pure profit bonus then their position becomes strategically weak, is confirmed: also the managerial delegation game with CSR-type firms is a prisoner's dilemma game.

\section{Conclusions}

In a duopoly market where firms are "socially responsible", this paper examines the effects of the managerial delegation on the equilibrium outcomes. In particular, the endogenous choice between the most common manager's bonus schemes, i.e. sales delegation (D), "relative profits" (RP) and "pure CSR objective function" (PCSR) is analysed making use of a standard game-theoretic approach. It is shown that the subgame perfect Nash equilibrium is the common choice of the RP scheme, whereas the CSR firm's objective function would be highest (lowest) under the PCSR (D) choice. Therefore, the well-known prisoner's dilemma nature of the managerial delegation game holds also when firms adopt CSR behaviours. Overall, these findings shed new light on the issue of the managerial delegation in the recently increasing cases of social concerned firms.

Open Access This article is distributed under the terms of the Creative Commons Attribution 4.0 International License (http://creativecommons.org/licenses/by/4.0/), which permits unrestricted use, distribution, and reproduction in any medium, provided you give appropriate credit to the original author(s) and the source, provide a link to the Creative Commons license, and indicate if changes were made.

\section{References}

Baron DP (2001) Private politics, corporate social responsibility, and integrated strategy. J Econ Manag Strategy 10:7-45

Baron DP (2009) A positive theory of moral management, social pressure, and corporate social performance. J Econ Manag Strategy 18:7-43

Baron DP, Diermeier D (2007) Special issue on nonmarket strategy and social responsibility. J Econ Manag Strategy 16(3):539-792

Baumol W (1958) On the theory of oligopoly. Economica 25:187-198

Benabou R, Tirole J (2010) Individual and corporate social responsibility. Economica 77:1-19

Bennett J, Iossa E, Legrenzi G (2003) The role of commercial non-profit organizations in the provision of public services. Oxford Rev Econ Policy 19:335-347 
Benz M (2005) Not for profit, but for satisfaction? Evidence on worker well-being in non-profit firms. Kyklos 58:155-176

Berle AA, Means GC (1932) The modern corporation and private property. Harcourt, Brace and World, New York

Besley T, Ghatak M (2010) Retailing public goods: the economics of corporate social responsibility. J Publ Econ 91:1645-1663

Fanti L, Buccella D (2016) Corporate social responsibility in a game theoretic context. Econ Polit Indust 44(3):371-390

Fanti L, Buccella D (2017) Corporate social responsibility, profits and welfare with managerial firms. Int Rev Econ 64(4):341-356

Fanti L, Meccheri N (2013) Managerial delegation under alternative unionization structures. Labour 27:38-57

Fanti L, Gori L, Sodini M (2017) Managerial delegation theory revisited. Manag Decis Econ 38(4):490-512

Fershtman C, Judd K (1987) Equilibrium incentives in oligopoly. Am Econ Rev 77:927-940

Gibbons R, Murphy KJ (1990) Relative performance evaluation for chief executive officers. Ind Labor Relat Rev 43:30S-51S

Goering GE (2007) The strategic use of managerial incentives in a non-profit firm mixed duopoly. Manag Decis Econ 28:83-91

Goering GE (2008) Welfare impacts of a non-profit firm in mixed commercial markets. Econ Syst 32:326-334

Holmström B (1982) Moral hazard in teams. Bell J Econ 13:324-340

Jansen T, van Lier A, van Witteloostuijn A (2007) A note on strategic delegation: the market share case. Int J Ind Organ 25:531-539

Jansen T, van Lier A, van Witteloostuijn A (2009) On the impact of managerial bonus systems on firm profit and market competition: the cases of pure profit, sales, market share and relative profits compared. Manag Decis Econ 30:141-153

Jansen T, van Lier A, van Witteloostuijn A (2012) Managerial bonus systems in a differentiated duopoly: a comment. Manag Decis Econ 33:61-70

Jensen MC (2001) Value maximization, stakeholder theory, and the corporate objective function. J Appl Corporation Finan 14(3):8-21

Jensen MC, Murphy KJ (1990) Performance pay and top management incentives. J Polit Econ 98:225-264

Kopel M (2015) Price and quantity contracts in a mixed duopoly with a socially concerned firm. Manag Decis Econ 36(8):559-566

Kopel M, Brand B (2012) Socially responsible firms and endogenous choice of strategic incentives. Econ Model 29:982-989

KPMG (2011) KPMG survey of corporate responsibility reporting 2013. https://www.kpmg.com/PT/pt/ IssuesAndInsights/Documents/corporate-responsibility2011.pdf

KPMG (2013) KPMG survey of corporate responsibility reporting 2013. https://assets.kpmg.com/content/ $\mathrm{dam} / \mathrm{kpmg} / \mathrm{pdf} / 2015 / 08 / \mathrm{kpmg}$-survey-of-corporate-responsibility-reporting-2013.pdf

KPMG (2015) The KPMG survey of corporate responsibility reporting 2015. https://assets.kpmg.com/ content/dam/kpmg/pdf/2016/02/kpmg-international-survey-of-corporate-responsibility-reporting2015.pdf

Lambertini L, Tampieri A (2010) Corporate social responsibility in a mixed oligopoly. Department of Economics, University of Bologna Working paper 723

Lambertini L, Tampieri A (2011) On the stability of mixed oligopoly equilibria with CSR firms. Department of Economics, University of Bologna Working paper 768

Lambertini L, Tampieri A (2012) Corporate social responsibility and firms ability to collude. In: Boubaker S, Nguyen D (eds) Board directors and corporate social responsibility. Palgrave Macmillan, UK

Lambertini L, Tampieri A (2015) Incentives, performance and desirability of socially responsible firms in a Cournot oligopoly. Econ Model 50:40-48

Lambertini L, Palestini A, Tampieri A (2016) CSR in an asymmetric duopoly with environmental externality. South Econ J 83:236-252

Manasakis C, Mitrokostas E, Petrakis E (2011) Endogenous managerial incentive contracts in a differentiated duopoly, with and without commitment. Manag Decis Econ 31:531-543

Manasakis C, Mitrokostas E, Petrakis E (2014) Strategic corporate social responsibility activities and corporate governance in imperfectly competitive markets. Manag Decis Econ 35:460-473 
Meccheri N, Fanti L (2014) Managerial delegation contracts under centralized unionization. Manag Decis Econ 35:51-66

Miller N, Pazgal A (2002) Relative performance as a strategic commitment mechanism. Manag Decis Econ 23:51-68

Planer-Friedrich L, Sahm M (2017) Strategic corporate social responsibility. BERG Working Paper Series, No. 124

Reputation Institute (2016) 2016 Global CSR RepTrak 100. https://www.reputationinstitute.com/2016Global-CSR-RepTrak.aspx

Salas Fumás V (1992) Relative performance evaluation of management. Int J Ind Organ 10:473-489

Schiff J, Weisbrod B (1991) Competition between for-profit and nonprofit organizations in commercial markets. Ann Publ Coop Econ 62:619-639

Sklivas SD (1987) The strategic choice of managerial incentives. RAND J Econ 18:452-458

Vickers J (1985) Delegation and the theory of the firm. Econ J 95:138-147 